\title{
Characteristics of the Measurement Tools for Assessing Health Information-Seeking Behaviors in Nationally Representative Surveys: Systematic Review
}

\author{
Hanna Choi ${ }^{1 *}$, MSN, PhD; Gyeonghui Jeong ${ }^{2,3 *}$, MSc \\ ${ }^{1}$ Department of Nursing Science, Nambu University, Gwangju, Republic of Korea \\ ${ }^{2}$ College of Nursing, Chonnam National University, Gwangju, Republic of Korea \\ ${ }^{3}$ College of Nursing, Seoul National University, Seoul, Republic of Korea \\ $*^{*}$ all authors contributed equally
}

Corresponding Author:

Gyeonghui Jeong, MSc

College of Nursing

Chonnam National University

160 Baekseo-ro, Dong-gu

Gwangju, 61469

Republic of Korea

Phone: 821049995110

Fax: 82622274009

Email: gyeonghui.jeong@gmail.com

\section{Abstract}

Background: The coronavirus pandemic (COVID-19) has also emerged as an infodemic, thereby worsening the harm of the pandemic. This situation has highlighted the need for a deeply rooted understanding of the health information-seeking behaviors (HISBs) of people.

Objective: The aim of this paper was to review and provide insight regarding methodologies and the construct of content in HISB surveys by answering the following research question: what are the characteristics of the measurement tools for assessing HISBs in nationally representative surveys around the world?

Methods: The Preferred Reporting Items for Systematic Reviews and Meta-Analyses was used as the framework for this study. A data search was performed through 5 international and 2 Korean databases covering the years between 2008 and 2020. Initially, studies performed among nationally representative samples were included to discover HISB survey instruments. The methodologies of the studies using HISB surveys were analyzed. For content analysis, 2 researchers reached a consensus through discussion by scrutinizing the contents of each survey questionnaire.

Results: A total of 13 survey tools from 8 countries were identified after a review of 2333 records from the search results. Five survey tools (Health Information National Trends Survey, Health Tracking Survey, Annenberg National Health Communication Survey, National Health Interview Survey, and Health Tracking Household Survey) from the United States, 2 instruments from Germany, and 1 tool from each of the countries of the European Union, France, Israel, Poland, South Korea, and Taiwan were identified. Telephone or web-based surveys were commonly used targeting the adult population ( $\geq 15$ years of age). From the content analysis, the domains of the survey items were categorized as follows: information (information about health and patient medical records), channel (offline and online), and health (overall health, lifestyle, and cancer). All categories encompassed behavioral and attitude dimensions. A theoretical framework, that is, an information-channel-health structure for HISBs was proposed.

Conclusions: The results of our study can contribute to the development and implementation of the survey tools for HISB with integrated questionnaire items. This will help in understanding HISB trends in national health care.

(J Med Internet Res 2021;23(7):e27539) doi: 10.2196/27539 


\section{KEYWORDS}

information seeking behavior; consumer health information; medical informatics; health care surveys; health information-seeking behavior; surveys

\section{Introduction}

\section{Background}

The recent global pandemic of COVID-19, determined to be a public health emergency of international concern, has changed many aspects of people's daily lives [1]. When people wake up, they check health-related news, their signs and symptoms, methods of prevention, and restrictions on the use of a vaccine. While mass media have been releasing a myriad of information, individuals have also been reproducing and downloading news and information from internet webpages such as websites or blogs $[2,3]$. The tsunami of information has resulted in the production of several fake news that lack scientific evidence and convey misconceptions and misinformation about health [4]. In reality, misguided belief based on misinformation has caused the deaths of many people [5] and worsened COVID-19 infections [6,7]. In this way, the rise of incorrect information has led to abuse, or in other words, an infodemic [4,8]. The foremost solution to mitigate this issue would be to understand the information-seeking behaviors of individuals. It would be beneficial if governments or national institutes measure their behaviors to apply health and information policies appropriately [9].

Health information-seeking behavior (HISB) is a comprehensive term that describes an individual's behavior of seeking information, including the intentional collection and unintentional receipt of information [10,11]. Some studies have shown HISBs by using certain measurement tools such as Health Information National Trends Survey (HINTS), Health Tracking Survey, and the Annenberg National Health Communication Survey (ANHCS). The limitations of these studies are that most surveys mainly target American subjects or web-based/digital HISB [12-18]. These limitations can be overcome by the design of a comprehensive survey instrument. Survey instruments are developed to collect information for certain research phenomena [19] or for finding the right answers by asking the right questions. It would be efficient and effective to obtain a holistic view by integrating the properties of worldwide national survey tools in a systematic approach and by scrutinizing the constructs and methodologies, including what aspects of HISBs are considered important or are missed out. Although there are preliminary studies using systematic reviews of HISB instruments, these topics are limited to the context of the United States and eHealth, thereby making it difficult to look into cross-national HISB [17,20]. Therefore, this study aims to review how HISBs are measured by identifying and comparing measurement tools based on nationwide surveys.

\section{Objectives}

The aim of this paper was to provide insights on the methodologies and the construct of content for HISB survey instruments based on nationally representative surveys.

\section{Methods}

\section{Research Question}

The SPIDER (sample, phenomenon of interest, design, evaluation, and research type) format was used to formulate the research question for this review [21,22]: what are the characteristics of measurement tools (evaluation) for assessing HISBs (phenomenon of interest) in nationally representative surveys around the world (sample and design)?

\section{Protocol and Registration}

This study was conducted in accordance with Preferred Reporting Items for Systematic Reviews and Meta-Analyses [23]. The protocol of this review paper is registered in PROSPERO (CRD42019122767).

\section{Eligibility Criteria}

To answer the research question, inclusion and exclusion criteria were established. Survey tools were included if they were full versions of the tools for HISBs and if they targeted nationally representative samples. However, tools were excluded when the full versions of the instruments were not accessible, not HISB-focused, nor used for a nationally representative sample.

\section{Information Sources}

As we seek in this study to discover the national survey tools for HISB, articles, reports, and related websites were searched for clues to detect those instruments. The data search was performed in 2 phases. The phase 1 search covering 2008 to 2017 was conducted between October 09, 2017 and November 13, 2017 through 7 databases: 5 international databases, namely, PubMed, CINAHL Complete (Ebsco), HaPI, PsycTESTS, and PsycINFO (Ebsco), and 2 Korean databases (RISS [Research Information Sharing Service] and DBpia). Phase 2 was performed between February 19, 2021 and March 25, 2021 to obtain recent literature covering 2017 to 2020 with the same search strategy (Figure 1, Multimedia Appendix 1). 
Figure 1. PRISMA flow diagram of literature search and selection process. CDC: Centers for Disease Control and Prevention; HINTS: Health Information National Trends Survey; HISB: health information-seeking behavior; RISS: Research Information Sharing Service; WHO: World Health Organization.
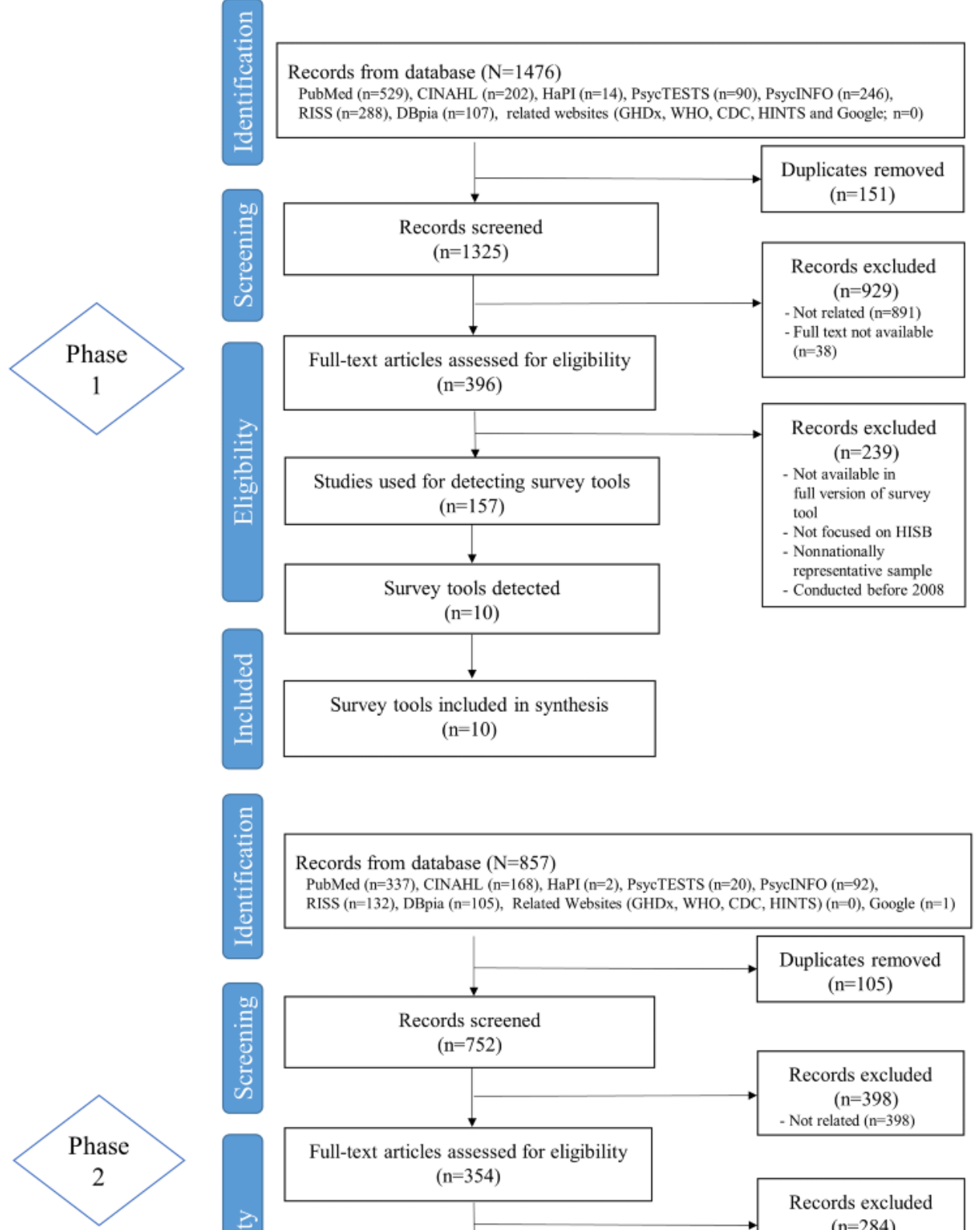

Records from database $(\mathrm{N}=857)$

PubMed ( $\mathrm{n}=337$ ), CINAHL ( $\mathrm{n}=168)$, HaPI ( $\mathrm{n}=2)$, PsycTESTS $(\mathrm{n}=20)$, PsycINFO $(\mathrm{n}=92)$,

RISS $(\mathrm{n}=132)$, DBpia ( $\mathrm{n}=105)$, Related Websites (GHDx, WHO, CDC, HINTS) $(\mathrm{n}=0)$, Google $(\mathrm{n}=1)$
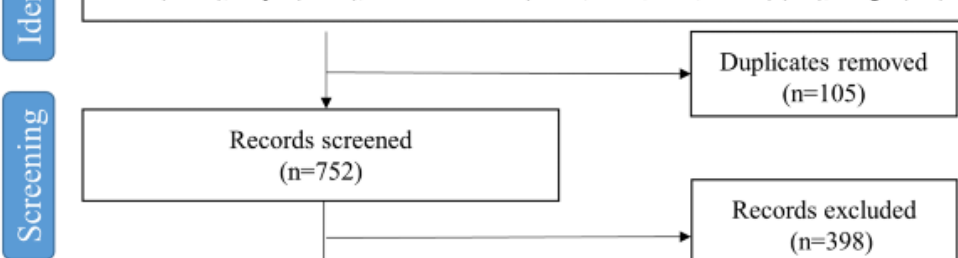

$(\mathrm{n}=105)$
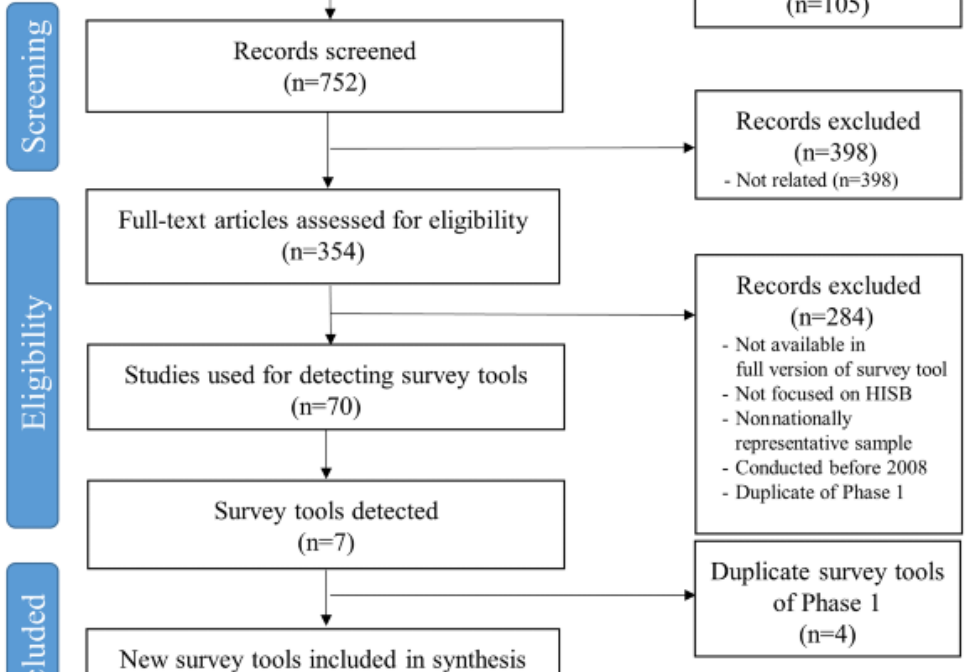

New survey tools included in synthesis

$(\mathrm{n}=3)$

\section{Search Strategy}

Pilot searches were performed by the authors, and the final search strategy with the consultation of a librarian was utilized with MeSH terms (ie, information-seeking behavior) and free-text searching as well as the Boolean operators "OR" and “AND" (Multimedia Appendix 1). There was no limit on languages, but publication years were restricted between 2008 and 2020: January 1, 2008 to November 13, 2017 for phase 1 and January 1, 2017 to December 31, 2020 for phase 2 .

\section{Study Selection and Data Collection Process}

Two authors (HC and GJ) initially reviewed the titles and abstracts of the papers and eliminated irrelevant documents. Then, HC and GJ scrutinized full-texts and filtered them according to the inclusion/exclusion criteria. As the purpose of 
the study was to seek nationally representative surveys of HISB, related websites were also accessed, such as that of The World Health Organization, which has the primary role of directing and coordinating international health, and Global Health Data Exchange [24], which is the most comprehensive catalog of surveys, censuses, vital statistics, and other health-related data in the world. In addition, to obtain the survey questionnaires, websites such as those of the National Cancer Institute, Centers for Disease Control and Prevention, European Commission, and Santé Publique France were searched. Academic papers, reports, and webpages identified through the previous steps were reviewed to discover HISB survey tools. To attain sufficient data (ie, full version of the item(s) of the survey, methodology, etc), we emailed 8 corresponding authors of the papers: 2 of the corresponding authors sent full version of the survey instruments, which were not related to the HISB; 1 author refused to provide a full version of the survey instrument; and 5 authors did not respond. To capture grey literature, footnote tracing was performed along with a review of the related websites described above. All documents identified through this process were managed with EndNote X20.0 software (Clarivate Analytics). During the whole process, consensus was reached through discussion if there was disagreement between the authors.

\section{Data Items}

We sought the characteristics of the selected instruments, including the name of the instrument, administrative institution, and funding sources, country, language, frequency of the survey, survey duration, sampling method, mode of survey administration, target population, total number of the population, and purpose of the measurement. In addition, the content of the survey instruments was scrutinized.

\section{Risk of Bias in Individual Studies}

The aim of this study was to identify the measures used to analyze HISB in national surveys. Therefore, this review paper focuses on questionnaires in the national surveys on HISB and the risk of bias assessment is not applicable.

\section{Synthesis of Results}

As this review is intended as content analysis, the authors thoroughly read the contents of the questionnaires of the selected HISB instruments. Themes emerged during this process as we used coding sheets with Excel and Word. The findings were provided through the process of reaching a consensus between the 2 authors on the coding sheets. Finally, the synthesized results were depicted in table and figure formats.

\section{Results}

\section{Study Selection}

A total of 2333 papers were identified through 2 phases of the search process. From phase 1 of the search, 1476 papers were identified in the following academic databases: PubMed $(\mathrm{n}=529)$, CINAHL $(\mathrm{n}=202)$, HaPI $(\mathrm{n}=14)$, PsycTESTS $(\mathrm{n}=90)$, PsycINFO $(\mathrm{n}=246)$, RISS $(\mathrm{n}=288)$, and DBpia $(\mathrm{n}=107)$. Duplicates $(n=151)$ were removed and 929 papers were eliminated. A total of 396 full-texts were reviewed and 157 documents were used for detecting 10 survey tools: (1) HINTS [25], (2) Health Tracking Survey [26], (3) ANHCS [27] $(n=5)$, (4) National Health Interview Survey (NHIS) [28], (5) Health Tracking Household Survey (HTHS) [29], (6) Flash Eurobarometer [30], (7) Baromètre Santé [31], (8) Gesundheitsmonitor [32], (9) Israeli survey [33], and (10) eHealth Consumer Trend Survey [34].

Phase 2 was performed to update the recent survey tools by using the same search strategy. As a result, 857 records were identified: PubMed ( $n=337)$, CINAHL $(n=168)$, HaPI $(n=2)$, PsycTESTS ( $n=20)$, PsycINFO ( $n=92)$, RISS ( $n=132)$, DBpia $(\mathrm{n}=105)$, and Google $(\mathrm{n}=1)$. Duplicates $(\mathrm{n}=105)$ were excluded, and 398 records were also removed after screening. The full texts of 354 papers were reviewed, and 70 records were used for detecting 7 survey tools. There were 4 duplicates of survey tools from phase 1 . Therefore, 3 more survey tools, that is, Stiftung Gesundheitswissen (HINTS Germany) [35], survey of cancer and health-related information-seeking behavior (CHISB) for Koreans [36], and Taiwan Communication Survey [37] were also included for synthesis.

A total of 227 papers were related to the selected HISB instruments (Multimedia Appendix 2). About 96\% of them $(219 / 227)$ were related to 1 of the 5 US surveys: HINTS [25] $(\mathrm{n}=188)$, the Health Tracking Survey [26] $(\mathrm{n}=9)$, ANHCS [27] $(\mathrm{n}=7)$, NHIS [28] $(\mathrm{n}=11)$, and HTHS [29] $(\mathrm{n}=4)$. The remaining 8 studies identified 8 survey tools used in other parts of the world, that is, European Union (Flash Eurobarometer) [30] $(n=1)$, France (Baromètre santé) [31] $(n=1)$, Germany (Gesundheitsmonitor [32] [n=1] and HINTS Germany) [35] $[\mathrm{n}=1])$, Israeli survey [33] $(\mathrm{n}=1)$, Poland (eHealth Consumer Trend Survey) [34] ( $n=1)$, South Korea (survey of CHISB) [36] $(\mathrm{n}=1)$, and Taiwan (Taiwan Communication Survey) [37] $(\mathrm{n}=1)$. Therefore, 13 survey instruments (Table 1, Multimedia Appendix 3) were included in this review [38-77]. 
Table 1. Brief characteristics of the instruments for measuring health information-seeking behaviors in nationally representative survey studies.

\begin{tabular}{|c|c|c|c|c|c|c|}
\hline Country & Instrument & $\begin{array}{l}\text { Survey } \\
\text { version }\end{array}$ & Purpose of the measurement & Frequency & Target population & $\begin{array}{l}\text { Total population } \\
\text { in the survey }(\mathrm{N})\end{array}$ \\
\hline USA & $\begin{array}{l}\text { Health Information Na- } \\
\text { tional Trends Survey } \\
\text { (HINTS) [38-41] }\end{array}$ & $\begin{array}{l}2019, \\
\text { HINTS 5, } \\
\text { Cycle } 3\end{array}$ & $\begin{array}{l}\text { To investigate respondents' ac- } \\
\text { cess to and use of health informa- } \\
\text { tion, including information tech- } \\
\text { nology to manage health and } \\
\text { health information }\end{array}$ & $\begin{array}{l}\text { Every few years } \\
(1-2 \text { year cycle })\end{array}$ & $\begin{array}{l}\text { Civilian noninstitutional- } \\
\text { ized adults aged } 18 \text { years } \\
\text { or older }\end{array}$ & 5247 \\
\hline USA & $\begin{array}{l}\text { Health Tracking Survey } \\
{[42-50]}\end{array}$ & 2012 & $\begin{array}{l}\text { To assess pursuit of health taking } \\
\text { place within a widening network } \\
\text { of both online and offline sources }\end{array}$ & Irregular & $\begin{array}{l}\text { Adults aged } 18 \text { years or } \\
\text { older }\end{array}$ & 3014 \\
\hline USA & $\begin{array}{l}\text { Annenberg National } \\
\text { Health Communication } \\
\text { Survey [18,51-56] }\end{array}$ & 2012 & $\begin{array}{l}\text { To capture national trends related } \\
\text { to health behavior and behavioral } \\
\text { intentions to media exposure, } \\
\text { health knowledge and beliefs, } \\
\text { and policy preferences and be- } \\
\text { liefs }\end{array}$ & $\begin{array}{l}\text { One-cycle sur- } \\
\text { vey }\end{array}$ & $\begin{array}{l}\text { Adults aged } 18 \text { years or } \\
\text { older }\end{array}$ & 3692 \\
\hline USA & $\begin{array}{l}\text { National Health Inter- } \\
\text { view Survey [57-67] }\end{array}$ & 2020 & $\begin{array}{l}\text { To monitor the health of the } \\
\text { population through the collection } \\
\text { and analysis of the data }\end{array}$ & Annual & Household & $33,138^{\mathrm{a}}$ \\
\hline USA & $\begin{array}{l}\text { Health Tracking } \\
\text { Household Survey } \\
{[68-71]}\end{array}$ & 2010 & $\begin{array}{l}\text { To inform health care decision } \\
\text { makers about changes in the } \\
\text { health care system and the influ- } \\
\text { ence }\end{array}$ & $\begin{array}{l}\text { Irregular }(2-5 \\
\text { year period) }\end{array}$ & Household & $\begin{array}{l}16,671 \text { individu- } \\
\text { als ( } \mathrm{n}=9165 \text { Fam- } \\
\text { ily Insurance } \\
\text { Units) }\end{array}$ \\
\hline Europe & $\begin{array}{l}\text { Flash Eurobarometer } \\
404 \text { (European citizen's } \\
\text { digital health literacy) } \\
\text { [72] }\end{array}$ & 2014 & $\begin{array}{l}\text { To support increasing use of } \\
\text { digital health care to help man- } \\
\text { age citizen's own health }\end{array}$ & $\begin{array}{l}\text { One-cycle sur- } \\
\text { vey }\end{array}$ & $\begin{array}{l}\text { EU residents aged } 15 \\
\text { years and older }\end{array}$ & $\begin{array}{l}26,566(28 \mathrm{EU} \\
\text { countries) }\end{array}$ \\
\hline France & $\begin{array}{l}\text { French Health Barome- } \\
\text { ter (Baromètre santé) } \\
\text { [73] }\end{array}$ & 2017 & $\begin{array}{l}\text { To gain a better understanding } \\
\text { of French health knowledge, atti- } \\
\text { tudes, beliefs, and behaviors }\end{array}$ & Annual & Adults aged $18-75$ years & $15,635^{\mathrm{b}}$ \\
\hline Germany & $\begin{array}{l}\text { Gesundheitsmonitor } \\
\text { [74] }\end{array}$ & 2015 & $\begin{array}{l}\text { To assess health-related knowl- } \\
\text { edge, attitudes, and behaviors }\end{array}$ & Annual & Adults aged $18-79$ years & 1598 \\
\hline Germany & HINTS Germany [75] & 2019 & $\begin{array}{l}\text { To close the gap in important } \\
\text { health-related information ac- } \\
\text { tions and systematical health } \\
\text { records }\end{array}$ & $\begin{array}{l}\text { Every few years } \\
(1-2 \text { year cycle })\end{array}$ & Adults aged $18-79$ years & 2902 \\
\hline Israel & Not titled survey [33] & 2014 & $\begin{array}{l}\text { To measure eHealth literacy for } \\
\text { others, including perceived out- } \\
\text { come of internet use }\end{array}$ & $\begin{array}{l}\text { One-cycle sur- } \\
\text { vey }\end{array}$ & $\begin{array}{l}\text { Adult aged } 21 \text { years and } \\
\text { older }\end{array}$ & 819 \\
\hline Poland & $\begin{array}{l}\text { eHealth Consumer } \\
\text { Trend Survey } 2012^{c} \\
{[76]}\end{array}$ & 2012 & $\begin{array}{l}\text { To show the trends in the percep- } \\
\text { tions and preferences of Polish } \\
\text { citizens regarding internet use } \\
\text { and factors affecting their usage }\end{array}$ & Irregular & Adults aged $15-80+$ years & 1000 \\
\hline $\begin{array}{l}\text { South Ko- } \\
\text { rea }\end{array}$ & $\begin{array}{l}\text { Survey of cancer and } \\
\text { health-related informa- } \\
\text { tion-seeking behavior } \\
\text { for Koreans [36] }\end{array}$ & 2018 & $\begin{array}{l}\text { To capture national phenomena } \\
\text { of cancer and health-related } \\
\text { health information-seeking be- } \\
\text { havior of Koreans }\end{array}$ & $\begin{array}{l}\text { One-cycle sur- } \\
\text { vey }\end{array}$ & Adults aged $18-65+$ years & 1012 \\
\hline Taiwan & $\begin{array}{l}\text { Taiwan Communication } \\
\text { Survey [77] }\end{array}$ & 2016 & $\begin{array}{l}\text { To explore media use behaviors } \\
\text { among the general public, includ- } \\
\text { ing health, risk, and disaster } \\
\text { communication }\end{array}$ & Annual & $\begin{array}{l}\text { Adults aged } 18 \text { years and } \\
\text { older }\end{array}$ & 2098 \\
\hline
\end{tabular}

a2019 sample size was reported. Data and report for 2020 will be published in fall 2021.

${ }^{b}$ French Health Barometer: the survey questionnaires were changed according to the survey years. The 2017 version of the survey contains health information-seeking behavior and is included in this study.

${ }^{c}$ eHealth consumer trend survey of 2012 was modified from the eHealth Consumer Trends Survey (2007), which was conducted in Denmark, Germany, Greece, Latvia, Norway, Poland, and Portugal in the World Health Organization/European eHealth Consumer Trends project $[78,79]$. 


\section{Key Characteristics of the Surveys}

\section{Country}

HISB surveys were found in 8 countries (Table 1, Multimedia Appendix 3). The United States has 5 HISB surveys (HINTS, Health Tracking Survey, ANHCS, NHIS, and HTHS), and the other 7 countries or regions, namely, the European Union, France, Germany, Israel, Poland, South Korea, and Taiwan conduct surveys called Flash Eurobarometer, Baromètre santé, Gesundheitsmonitor, Israeli survey (not titled), the eHealth consumer trend survey, survey of CHISB for Koreans, and Taiwan Communication Survey, respectively.

\section{Language}

As the surveys focused on domestic people, official or national languages were used (Table 1, Multimedia Appendix 3). For instance, the HINTS from the United States used 2 versions of the survey: English and Spanish. The European Union also performed the survey using the mother tongue of the responders.

\section{Instrument and Administration Institution}

HISB surveys were administered by national, nonprofit, public institutions, or individual researchers (Table 1, Multimedia Appendix 3). Five instruments, that is, HINTS, Flash Eurobarometer, NHIS, Baromètre santé, and Taiwan Communication Survey, were developed and administered by national institutes, namely, the National Cancer Institute in the United States, the National Center for Health Statistics in the United States, the Directorate-General for Communications Networks of the European Commission, the National Institute for Prevention and Health Education in France, and the Ministry of Science Technology in Taiwan, respectively. Four instruments were obtained from nonprofit institutions: the Pew Research Center (HINTS), the Center for Studying Health System Change (ceased operation in 2013) (HTHS), Bertelsmann Stiftung (Gesundheitsmonitor), and Gesundheitswissen and Hanover Center for Health Communication at the Institute for Journalism and Communication Research (HINTS Germany). A survey (ANHCS) was conducted by 2 public institutions, namely, the Annenberg Schools for Communication at the University of Pennsylvania and the University of Southern California. Individual researchers developed 3 survey tools: the Israeli survey, the eHealth Consumer Trend Survey (Poland), and the survey of CHISB for Koreans (South Korea), with the Israeli and South Korean studies funded by national institutes.

\section{Frequency of the Survey}

The frequency of the surveys was found to be annual, every few years, one time, or irregular (Table 1, Multimedia Appendix 3). The annual or every few years surveys were HINTS (United States), NHIS (United States), Baromètre santé (France), Gesundheitsmonitor (Germany), HINTS Germany (Germany), and Taiwan Communication Survey (Taiwan). The others, namely, the Health Tracking Survey (United States), ANHCS (United States), HTHS (United States), Flash Eurobarometer 404, the Israeli survey, survey of CHISB for Koreans (South Korea), and eHealth Consumer Trend Survey (Poland) have been conducted once or irregularly.

\section{Sampling and Mode of Administration}

The most common approach has been randomization, in particular, sampling with random digit dialing and then administration through a computer-assisted telephone interview (Table 1, Multimedia Appendix 3). In addition, for sampling, two-stage sampling (stratifying sample addresses and selecting 1 adult within each household) was often used. When web-based panels were used for random sampling, units or strata layers divided by the population group, geographical districts, size of the settlement, and the locality's socioeconomic status were utilized to prevent clashes.

\section{Population}

The range of this study is restricted to researching tools used with adults (Table 1, Multimedia Appendix 3). The standard age of adulthood in each country varies from 15 years to 21 years. Mostly, adults are defined as people who are 18 years of age or older, but in Europe and Poland, those who are 15 years or older are considered part of the adult population. In Israel, people older than 21 years are considered adults.

\section{Purpose}

The purposes were similar among the measurements: to monitor the use of health information in accordance with the type of information technology such as online or offline (Table 1, Multimedia Appendix 3). However, the detailed outcome of the studies pursued was different. For instance, the Baromètre santé (France) aimed to discover knowledge, attitudes, and behaviors toward HISB; however, the ANHCS (United States) pursued HISB related to media exposure, health knowledge and beliefs, and policy preferences and beliefs.

\section{Content Analysis of the Instruments}

The contents of the questionnaire items for each tool were thematically reviewed and categorized by 2 researchers (HC and GJ). The themes were then merged and synthesized through consensus. Thus, 57 themes were detected and divided into 3 domains (Figure 2) and 7 subdomains: information, information about health and patient medical records; channel, offline and online; and health, overall health, lifestyle, and cancer. Two dimensions - attitude and behavior - were identified across the domains (Table 2, Multimedia Appendix 4). In this paper, attitude was defined as the emotional and cognitive tendency of a person toward a particular object, person, or thing, affecting behavior [80]. Behavior was also defined as an objectively observable activity [81]. 
Figure 2. Average percentage of theme occurrence in the domains.

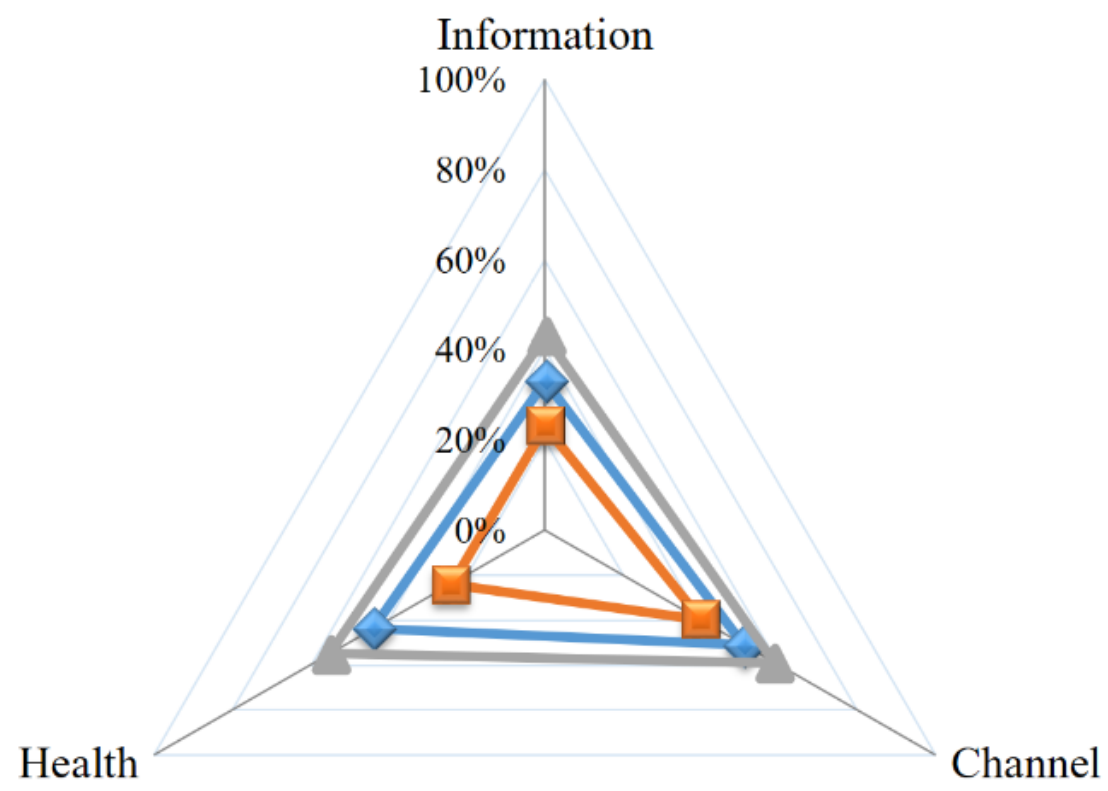

$\checkmark$ Total Occurrence $\quad-$-Attitude $\quad-$ Behavior 
Table 2. Content analysis of 13 representative national health information-seeking tools. ${ }^{\text {a }}$

\begin{tabular}{|c|c|c|c|c|}
\hline Domain, subdomain, dimension, theme & $\begin{array}{l}\text { Theme occurrence } \\
(\%)\end{array}$ & $\begin{array}{l}\text { Theme occurrence av- } \\
\text { erage percentage (SD) }\end{array}$ & $\begin{array}{l}\text { Subdomain average } \\
\text { percentage (SD) }\end{array}$ & $\begin{array}{l}\text { Domain average } \\
\text { percentage (SD) }\end{array}$ \\
\hline Information & & & & $33.0(14.9)$ \\
\hline Information about health & & & $44.9(14.9)$ & \\
\hline Attitude & & $26.9(5.4)$ & & \\
\hline Perceived ease of use & 30.8 & & & \\
\hline Perceived efficacy of seeking & 23.1 & & & \\
\hline Behavior & & $53.8(6.3)$ & & \\
\hline Search experience (frequency) & 46.2 & & & \\
\hline Information source & 61.5 & & & \\
\hline Type of information contents & 53.8 & & & \\
\hline Purpose of search (for whom) & 53.8 & & & \\
\hline Patient medical record & & & $24.0(6.4)$ & \\
\hline Attitude & & $21.5(6.4)$ & & \\
\hline Perceived privacy and confidentiality risk & 23.1 & & & \\
\hline Perceived ease of use & 15.4 & & & \\
\hline Perceived usefulness & 23.1 & & & \\
\hline Intention to use & 15.4 & & & \\
\hline Preference to provide access to others & 30.8 & & & \\
\hline Behavior & & $28.2(4.4)$ & & \\
\hline Access frequency & 30.8 & & & \\
\hline Type of information contents sought & 23.1 & & & \\
\hline Purpose of seeking a record & 30.8 & & & \\
\hline Channel & & & & $50.5(18.2)$ \\
\hline Offline & & & $50.5(15.9)$ & \\
\hline Attitude & & $41.0(4.4)$ & & \\
\hline Perceived credibility & 38.5 & & & \\
\hline Perceived ease of use & 38.5 & & & \\
\hline Satisfaction with service quality & 46.2 & & & \\
\hline Behavior & & $57.7(18.3)$ & & \\
\hline Access frequency & 84.6 & & & \\
\hline Type of health service & 46.2 & & & \\
\hline Communication with health care provider & 46.2 & & & \\
\hline Health-related decision making & 53.8 & & & \\
\hline Online & & & $50.5(19.7)$ & \\
\hline Attitude & & $39.6(15.0)$ & & \\
\hline Perceived credibility & 53.8 & & & \\
\hline Perceived ease of use & 38.5 & & & \\
\hline Perceived usefulness & 53.8 & & & \\
\hline Perceived eHealth literacy (technology efficacy) & 53.8 & & & \\
\hline Satisfaction with web-based information & 15.4 & & & \\
\hline Perceived confidentiality risks & 30.8 & & & \\
\hline Intention to use & 30.8 & & & \\
\hline
\end{tabular}


Health

\begin{tabular}{lc}
\hline Domain, subdomain, dimension, theme & $\begin{array}{l}\text { Them } \\
(\%)\end{array}$ \\
\hline Behavior & 92.3 \\
Access frequency & 61.5 \\
Type of information technology device & 46.2 \\
Health-related web and app (software use) & 53.8 \\
Web-based resource (governmental website, & \\
Wikipedia, etc) & 76.9 \\
Communication (consult) with health care & \\
provider & 61.5 \\
Communication with friends and others (social & \\
media, forum, etc) & 69.2 \\
Health-related decision making & 38.5 \\
Tracking/managing health state & 30.8
\end{tabular}

Theme occurrence

6.2

53.8

76.9

61.5

30.8

\section{Overall health}

\section{Attitude}

\section{Behavior}

Lifestyle

\section{Attitude}

\section{Behavior}

Cancer

\section{Attitude}

\section{Behavior}

Perceived health efficacy

Concerns and belief about health

\section{General health state}

Diseases diagnosed

Height

Weight

Mental health

Caregiving

Social support

Perception about nutrition

Perception about physical activity

Perception about alcohol

Perception about tobacco

Nutrition

Physical activity

Alcohol

Tobacco

Perception about cancer

84.6

69.2

61.5

61.5

53.8

30.8

53.8 38.5

30.8

7.7

15.4

23.1

30.8

61.5

53.8

53.8

38.5

Cancer check-up
Theme occurrence average percentage (SD)

$59.0(19.2)$

$59.3(16.4)$

$50.0(13.3)$

53.8 (18.0)

44.2 (20.6)

$34.6(5.4)$

Subdomain average

Domain average percentage (SD) 


\begin{tabular}{clll}
\hline Domain, subdomain, dimension, theme & $\begin{array}{l}\text { Theme occurrence } \\
(\%)\end{array}$ & $\begin{array}{l}\text { Theme occurrence av- } \\
\text { erage percentage (SD) }\end{array}$ & $\begin{array}{l}\text { Subdomain average } \\
\text { percentage (SD) }\end{array}$ \\
\hline Cancer diagnosed & 61.5 & $\begin{array}{l}\text { Domain average } \\
\text { percentage (SD) }\end{array}$ \\
\hline
\end{tabular}

${ }^{\text {a }}$ Total average percentage of the themes=44.0 (SD 19.3), total average percentage of attitude themes=30.4 (SD 13.5), and total average percentage of behavior themes $=53.8($ SD 16.9).

\section{Thematic Map}

Three domains, namely, information, channel, and health (Figure 2) emerged through the content analysis (Table 2). The highest rate of theme occurrence among the domains was channel (average percentage $50.5 \%$, SD 18.2), followed by health (average percentage 44.2\%, SD 20.6) and information (average percentage $33.0 \%$, SD 14.9).

\section{Information}

Information is a health-related, content-focused domain sought by the individual. There are 2 subdomains (Figure 3), namely, information about health and patient medical records. The information about the health subdomain was conceptualized by categorizing question items related to general health information through a set of options with comprehensive channels (online or offline). Patient medical records were related to a seeker's use of medical records online or offline. There were attitude and behavioral aspects for the themes found, and the detailed and representative questionnaire items of the themes are presented in Table 3. The subdomain information about health (average percentage 44.9\%, SD 14.9), which consisted of 6 themes, was more commonly used among the selected tools than patient medical records (average percentage $24.0 \%$, SD 6.4), which consisted of 8 themes. In both subdomains, the percentages of behavior-related themes was 1.3-2.0 times higher than those related to attitude.

Figure 3. Average percentage of theme occurrence in the subdomains.

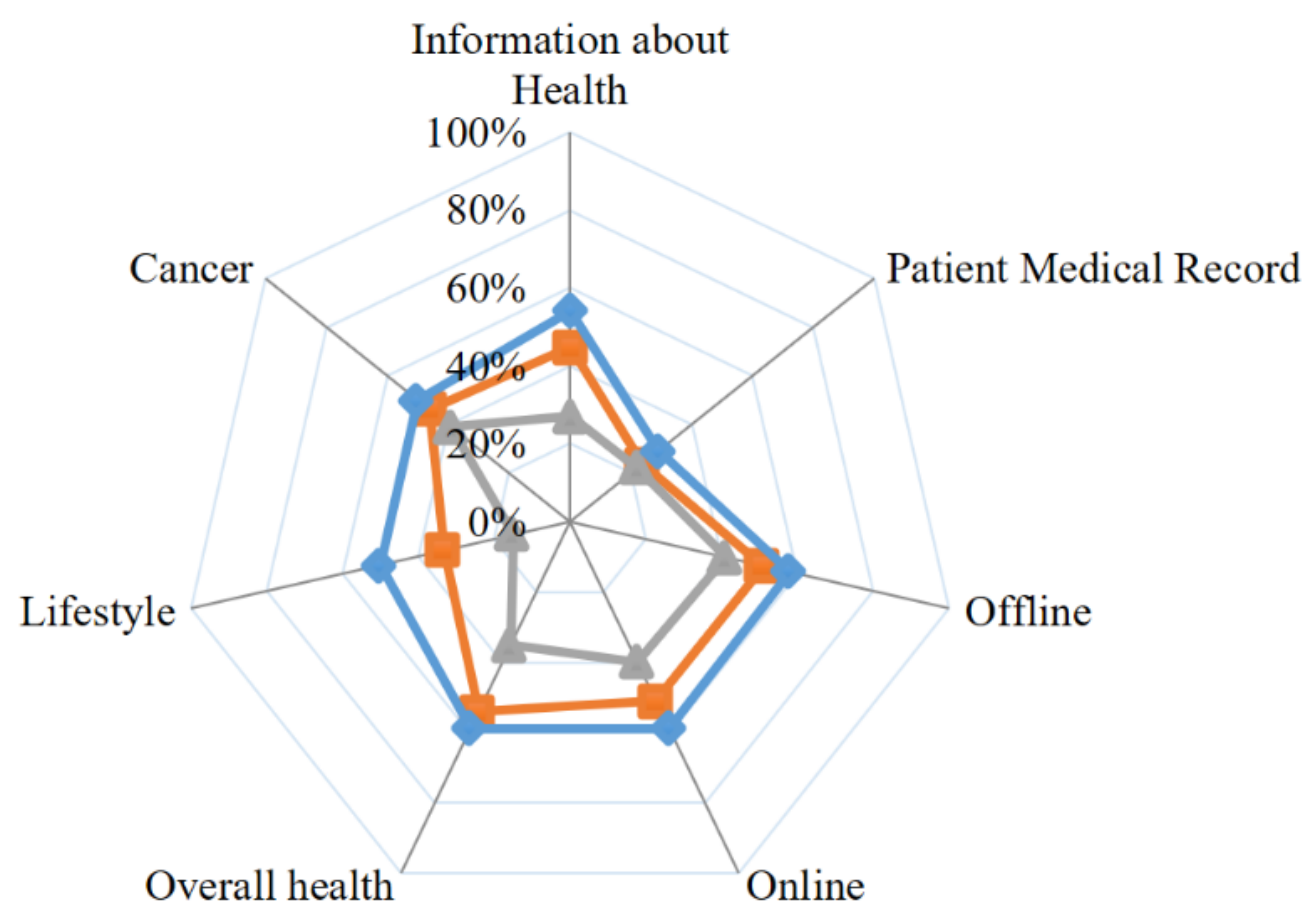


Table 3. Representative sample questionnaire items for health information-seeking behavior survey instruments.

\begin{tabular}{|c|c|}
\hline Domain, subdomain, dimension, theme & Questionnaire items \\
\hline \multicolumn{2}{|l|}{ Information } \\
\hline \multicolumn{2}{|l|}{ Information about health } \\
\hline \multicolumn{2}{|l|}{ Attitude } \\
\hline Perceived ease of use & $\begin{array}{l}\text { How much do you agree or disagree- it took a lot of effort to get the information you needed } \\
\left(\text { HINTS }^{\text {a }}\right)\end{array}$ \\
\hline Perceived efficacy of seeking & How confident are you that you could get advice about health if you needed it (HINTS) \\
\hline \multicolumn{2}{|l|}{ Behavior } \\
\hline Seek experience & Have you ever looked for information about health or medical topics from any source? (HINTS) \\
\hline Information source & $\begin{array}{l}\text { Thinking about the last time you had a serious health issue, did you get information from (selection } \\
\text { of the information source)? (HTS }{ }^{\text {b }} \text { ) }\end{array}$ \\
\hline Type of information contents & What type of health-related information did you look for? (Europe) \\
\hline Purpose of search (whom for) & $\begin{array}{l}\text { The most recent time you looked for information about health or medical topics, who was it for? } \\
\text { (HINTS) }\end{array}$ \\
\hline
\end{tabular}

\section{Patient medical record}

\section{Attitude}

Perceived privacy and confidentiality Have you ever kept information from your health care provider because you were concerned risk about the privacy or security of your medical record? (HINTS)

Perceived ease of use How easy or difficult was it to understand the health information in your online medical record? (HINTS)

Perceived usefulness

In general, how useful is your online medical record for monitoring your health? (HINTS)

Intention to use

Was denken Sie heute, werden Sie sich Ihre medizinischen Daten und Unterlagen mit Hilfe der Karte zukünftig näher anschauen? (What do you think today, will you take a closer look at your medical data and documents with the help of the card in the future?) (Gesundheitsmonitor, Germany)

Preference to provide access to others In order to get a quick and valid diagnosis, I am positive about giving internet access to my medical record to a doctor in another location or abroad (Poland)

\section{Behavior}

Access frequency

Have you approached your family doctor, specialist, or other health professional(s) over the internet to read your health record? (Poland)

Type of information contents sought

귀하의 온라인 의료 기록에 다음과 같은 의료 정보가 포함되어 있습니까? (Do any of your online medical records include the following types of medical information?) (survey of $\mathrm{CHISB}^{\mathrm{c}}$ )

Purpose of seeking a record In the past 12 months, have you used your web-based medical record to...(look up test results, monitor your health, etc) (HINTS).

\section{Channel}

Offline

\section{Attitude}

Perceived credibility

Do you believe health-related information from medical staff at medical centers or pharmacies? (Taiwan)

Perceived ease of use

How difficult is it to contact a doctor or other health care providers at this place after their regular hours in case of urgent medical needs-very difficult, somewhat difficult, not too difficult, or not at all difficult? (HTHS)

Satisfaction with service quality

How satisfied are you with the health care you received in the past 12 months? (NHIS ${ }^{\mathrm{d}}$ )

\section{Behavior}

Access frequency

How many times have you personally been to the doctor within the last 12 months (Europe)

Type of health service

What kind of place do you go to most often - a clinic, doctor's office, emergency room, or some other place? (NHIS) 


\begin{tabular}{cl}
\hline Domain, subdomain, dimension, theme & Questionnaire items \\
\hline $\begin{array}{l}\text { Communication with health care } \\
\text { provider }\end{array}$ & $\begin{array}{l}\text { In the past } 12 \text { months, did health care provider talk with you about all of the different prescription } \\
\text { medicines you are using, including medicines prescribed by other doctors? (HTHS }\end{array}$ \\
Health related decision making & $\begin{array}{l}\text { The following questions are about your communication with all doctors, nurses, or other health } \\
\text { professionals you saw during the past } 12 \text { months: did they involve you in decisions about your } \\
\text { health care as much as you wanted (HINTS)? }\end{array}$
\end{tabular}

\section{Online}

Attitude

Perceived credibility

Selon vous, l'information de santé que vous avez obtenue la dernière fois est-elle crédible? (In your opinion, is the health information credible you obtained the last time (on the internet?) (France)

Perceived ease of use

In general, how comfortable do you feel. (using computers, internet, etc) $\left(\mathrm{ANHCS}^{\mathrm{f}}\right)$

Perceived usefulness

How useful was the health information you found online? (HTHS)

Perceived eHealth literacy

I know how to use the internet to answer my health questions (Israel)

Satisfaction with web-based information

Overall, how satisfied or not are you with the health-related information you found on the internet? (Europe)

Perceived confidentiality risks

There are different reasons for not approaching your family doctor, specialist, or other health professional(s) via the internet. Which reasons apply to you? (I worry about confidentiality) (Poland)

Intention to use

Next time you want to get information on health-related questions, how likely are you to use the internet? (Europe)

\section{Behavior}

Access frequency

Within the last 12 months, have you used the internet to search for health-related information? (Europe)

Type of information technology device

Please indicate if you have each of the following: tablet computer like an iPad, smartphone, etc? (HINTS)

Health-related web and app (software What kind of health apps do you currently have on your phone? (HTS) use)

Web-based resource (governmental website, Wikipedia, etc)

Communication with health care provider

Communication with friends and others (social media, forum, etc)

Health-related decision making

Tracking/managing health state

Improvement of health knowledge

Have you used any of the following internet resources for health information? (government websites, news sites, etc) (ANHCS)

Haben Sie diese Gesundheits-Apps auf Ihrem Tablet oder Smartphone schon einmal dazu genutzt, ... um auf Gespräche mit Ihrem Arzt, Heilpraktiker, Physiotherapeuten usw. besser vorbereitet zu sein? (Have you ever used these health apps on your tablet or smartphone...to be better prepared for discussions with your doctor, alternative practitioner, physiotherapist, etc? (HINTS Germany)

Still thinking just about the last 12 months, have you posted a health-related question online or shared your own personal health experience online in any way? (HTS)

Haben Sie diese Gesundheits-Apps auf Ihrem Tablet oder Smartphone schon einmal dazu genutzt, .... um zu entscheiden, wie mit einer Erkrankung umgegangen werden sollte? (Has your tablet or smartphone...helped you make a decision about how to treat an illness or condition? (HINTS Germany)

Has your tablet or smartphone helped you track progress on a health-related goal such as quitting smoking, losing weight, or increasing physical activity? (HINTS)

Improved your understanding of the symptoms, conditions, or treatments in which you were interested (Israeli survey)

Health

\section{Overall health}

\section{Attitude}

Perceived health efficacy

Overall, how confident are you about your ability to take good care of your health? (HINTS)

Concerns and belief about health

\section{Behavior}

General health state 


\begin{tabular}{ll}
\hline Domain, subdomain, dimension, theme & Questionnaire items \\
\hline Diseases diagnosed & $\begin{array}{l}\text { Are you now living with any of the following health problems or conditions (diabetes, high blood } \\
\text { pressure, etc) (HTS) } \\
\text { Height }\end{array}$ \\
Height & $\begin{array}{l}\text { About how much do you weigh, in pounds, without shoes? (HINTS) } \\
\text { Mental health }\end{array}$ \\
$\begin{array}{l}\text { Have you been diagnosed with any of the following medical conditions? (mental health condition) } \\
\text { (ANHCS) }\end{array}$ \\
$\begin{array}{l}\text { Are you a caregiver for an adult family member with any of the following medical conditions? } \\
\text { (Alzheimer disease, cancer, etc) (ANHCS) }\end{array}$ \\
Social support & $\begin{array}{l}\text { Is there anyone you can count on to provide you with emotional support when you need it, such } \\
\text { as talking over problems or helping you make difficult decisions? (HINTS) }\end{array}$
\end{tabular}

\section{Lifestyle}

\section{Attitude}

Perception about nutrition

Perception about physical activity

Perception about alcohol

Perception about tobacco

\section{Behavior}

Nutrition

Physical activity

Alcohol

Tobacco

Cancer

\section{Attitude}

Perception about cancer

\section{Behavior}

Cancer check-up

Cancer diagnosed
How likely is it that eating 5 or more servings of fruits and vegetables every day will (make you look better)? (ANHCS)

How likely is it that doing at least moderate exercise 3 or more times a week will (reduce your feelings of stress)? (ANHCS)

How much do you agree or disagree with each of the following statements? (alcohol increases your risk of cancer) (HINTS)

In your opinion, do you think that some smokeless tobacco products such as chewing tobacco, snus, and snuff are less harmful to a person's health than cigarettes? (HINTS)

In the past week, on average, how many servings of fruit did you eat or drink per day? Please include $100 \%$ fruit juice, and fresh, frozen or canned fruits. (ANHCS)

In a typical week, how many days do you do any physical activity or exercise of at least moderate intensity, such as brisk walking, bicycling at a regular pace, and swimming at a regular pace? (HINTS)

In your entire life, have you had at least 12 drinks of any type of alcoholic beverage? (NHIS)

Have you smoked at least 100 cigarettes in your entire life? (ANHCS)
귀하께서는 다음 문항에 얼마나 동의하십니까? ... 일상에서 접하는 모든 것이 암을 유발 하는 원인임 (How much do you agree or disagree with each of the following statements? ... It seems like everything causes cancer, There's not much you can do to lower your chances of getting cancer, etc) (survey of CHISB)

When did you have your most recent prostate-specific antigen test to check for prostate cancer? (ANHCS)

Have you ever been told by a doctor or other health professional that you had cancer or a malignancy of any kind? (NHIS)

\footnotetext{
${ }^{a}$ HINTS: Health Information National Trends Survey.

${ }^{\mathrm{b}}$ HTS: Health Tracking Survey.

${ }^{\mathrm{c}} \mathrm{CHISB}$ : cancer and health-related information-seeking behavior.

${ }^{d}$ NHIS: National Health Interview Survey.

${ }^{\mathrm{e}}$ HTHS: Health Tracking Household Survey.

${ }^{\mathrm{f}}$ ANHCS: Annenberg National Health Communication Survey.
}

\section{Channel}

The channel can be defined as the means-focused domain that enables seekers to acquire and transmit health information [50]. The contents of the questionnaires pointed out that there were 2 channels for HISB: offline and online. The offline channel includes any method that collects or transmits health information through non-web-based sources such as health care providers, books, magazines, friends, seminars, or other means, and the offline subdomain consists of 7 themes (Figure 3). The online channel refers to seeking health information via the internet 
with any information technology device; the online subdomain showed the largest number of themes, that is, 7 attitude and 9 behavior themes. The subdomains offline and online revealed a similar occurrence, with average percentages at $50.5 \%$ (SD 15.9 ) and $50.5 \%$ (SD 19.7), respectively. In particular, the average percentage of a behavioral dimension of the online channel, namely, access frequency, was counted as $92.3 \%$ in the selected HISB tools as well as $84.6 \%$ of the access frequency theme in the offline subdomain. The occurrence of behavior dimensions was 1.4-1.5 times that of the attitude dimensions.

\section{Health}

The health domain refers to the seeker's physical status and perceptions about health: overall health, lifestyle, and presence of cancer. Overall health refers to general health status, including physical, mental, and social health and concerns or beliefs about them. Lifestyle consists of 4 parts of a person's behavior and attitude: nutrition, physical activity, alcohol consumption, and tobacco consumption. Cancer themes focused on check-up and diagnosis with cancer perceptions. Overall health was the most frequently found subdomain out of the 7 subdomains (average percentage $53.8 \%$, SD 18.0). The other subdomains, namely, lifestyle and cancer, revealed an average percentage of $32.7 \%$ and 46.2\% with SD 21.3 and SD 13.3, respectively (Figure 3). In particular, the average percentage of behavioral themes in overall health and general health state accounted for $84.6 \%$ in the selected HISB tools, while perceptions about nutrition and physical activity accounted for the smallest percentage at $7.7 \%$. Similar to other domains, the occurrence of behavior dimensions on the domain was 1.3-3.3 times higher than those of attitude.

\section{Person Characteristics}

A person is the subject of HISB who seeks and utilizes information. A person's characteristics may affect HISB. The main considered characteristics throughout the instruments were age, sex or gender, nationality, race, language, education, income, occupational status, marital status, health literacy, health insurance, the number of household members, households with internet access, and preference for online or offline channels.

\section{Themes Addressed by the Tools}

The spider web diagram shows the average percentage of the themes in the selected HISB tools. Survey of CHISB (South Korea) and HINTS (United States) accounted for $89 \%$ (51/57) and $88 \%$ (50/57), respectively, which were found to be high average percentages among the tools (Figure 4). ANHCS (United States), HINTS Germany, and Gesundheitsmonitor (Germany) also contain 63\% (36/57), 61\% (35/57), and 49\% (28/57) of the contents of HISB, respectively. Other tools including the HTHS (United States), NHIS (United States), the Health Tracking Survey (United States), the Flash Eurobarometer (Europe), Baromètre santé (France), the eHealth Consumer Trend Survey (Poland), and Taiwan Communication Survey (Taiwan) showed similar percentages of $21 \%-39 \%$ (12-22 out of 57 themes). The other HISB measurement from Israel showed only $11 \%(6 / 57)$ of the contents. All the tools focused more, by far, on the behavioral dimension than on attitude, showing a total average percentage of $53.8 \%$ and $30.4 \%$, respectively; moreover, each average percentage of the behavior dimension accounted for 1.2-14.5 times more than the attitude throughout the instruments.

Figure 4. Average percentage of theme occurrence in health information-seeking behavior instruments. ANHCS: Annenberg National Health Communication Survey; HINTS: Health Information National Trends Survey; HISB: health information-seeking behavior; HTHS: Health Tracking Household Survey; NHIS: National Health Interview Survey; CHISB: cancer and health-related information-seeking behavior; TCS: Taiwan Communication Survey.

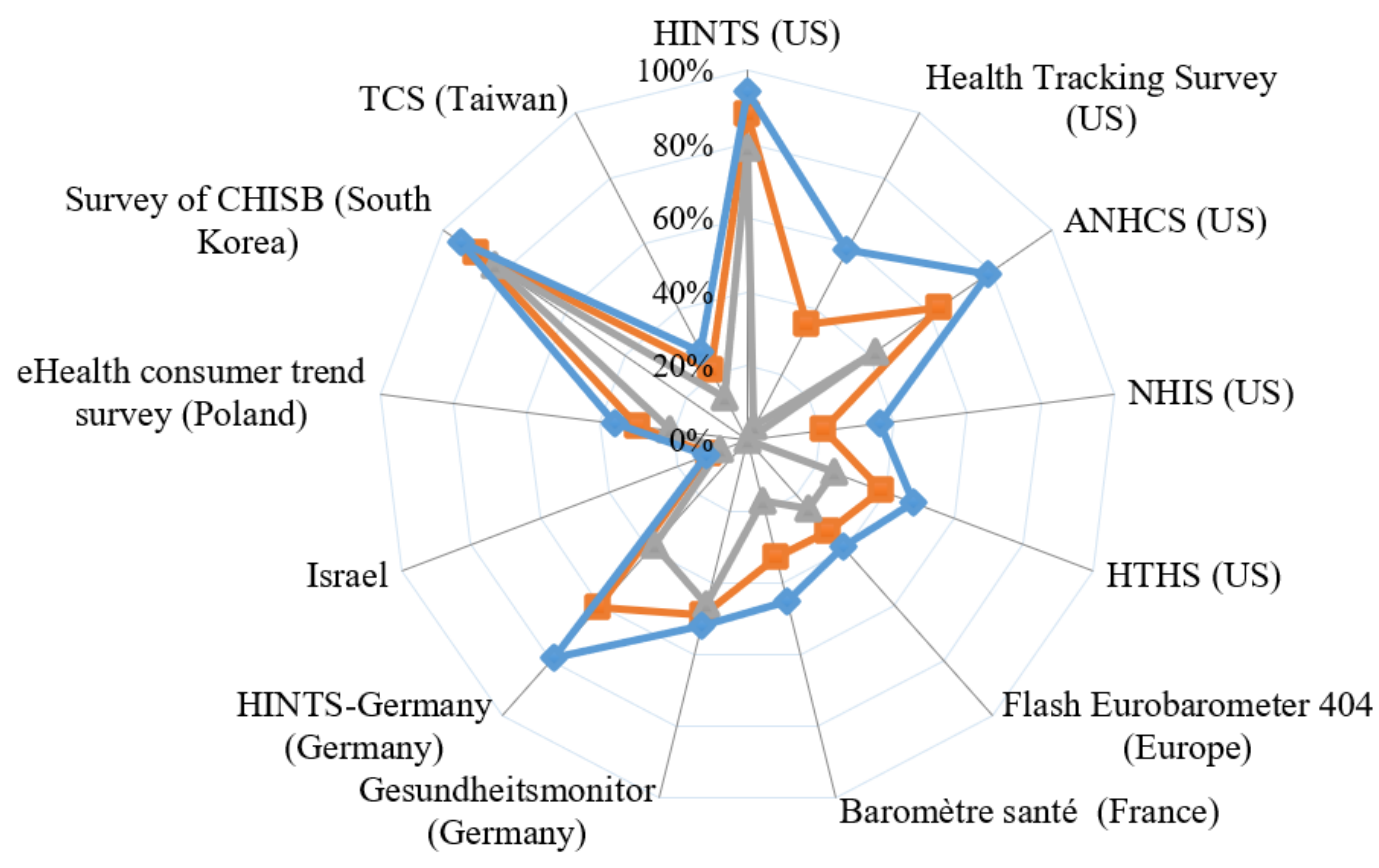

-Theme Occurrence $\rightarrow$ Attitude $\sim$ Behavior 


\section{Sample Questionnaire Items}

From the content analysis, representative sample questionnaire items from the 13 survey instruments were selected. Table 3 presents each questionnaire according to the domains, subdomains, and themes with attitude and behavior dimensions.

\section{Proposed Theoretical Construct for Assessing HISB}

Through the content analysis, a theoretical framework emerged. This study proposed the information-channel-health structure for assessing HISB (Figure 5). The theoretical structure shows reciprocal interaction between information and health through channels within the attitude and behavior dimensions. The information-channel-health concepts include the following: information, with information about health and patient medical records; channels, as online and offline; and health, with overall health state, lifestyle, and cancer. With the reciprocal structure of information-channel-health underlying 2 dimensions (attitude and behavior), the HISB phenomenon could be well illustrated with a comprehensive and holistic view.

Figure 5. A proposed theoretical construct for health information-seeking behavior.

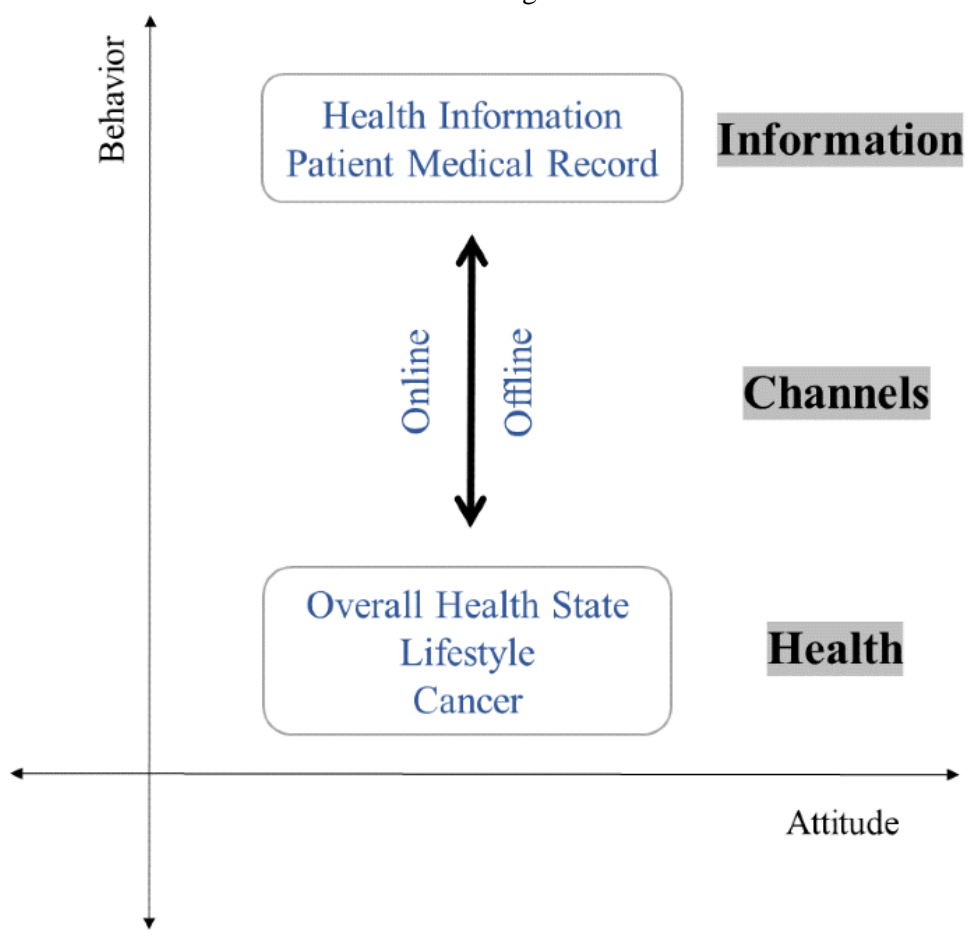

\section{Discussion}

\section{Principal Results}

In this study, we investigated the main characteristics of the methodologies and the contents of the HISB survey tools used for over more than a decade (2008-2020) to answer the following research question: what are the characteristics of the measurement tools for assessing HISBs in nationally representative surveys around the world? The aim of this paper is to provide insights on the methodologies and the construct of content for HISB survey instruments from nationally representative studies. Through the systematic search, 13 survey tools were found in 2333 records related to HISB surveys. The features of this study's results are comprehensive and not limited to specific countries and specific topics or issue-based research. Other HISB-related review studies reported specific data such as age, college enrollment, adulthood, needs, and disease, including adolescent disease [82-84]. However, in this study, the results of the analysis were based on a tool for surveying healthy adults, who account for the highest proportion of the population density. Such a tool can lead to changes in the national policy.

The United States was found to have the most influential survey; 5 out of 13 tools developed in various countries were included in this study, a total of 188 research papers used data from HINTS, and HINTS identified $88 \%$ (50/57 themes) of the constructs, according to the findings. These strong features might be related to the purpose of HINTS to investigate respondents' access to and use of health information, including information technology to manage health and health information. The composition of most of the questionnaire tools was continuously updated according to the change of the cycle. However, in the current survey of HINTS 5 Cycle 4, researchers changed its scope to focus on cancer compared to prior HINTS surveys, which focused on health and medical topics. Therefore, HINTS 5 Cycle 3 was included for the contents analysis part of this study. In particular, owing to the influence of COVID-19, the questionnaire in France was changed twice in 2020 only to reduce the time of survey completion.

The contents of each country's survey tools contain the construct of HISBs. They can be categorized as information (information about health and patient medical records), channel (online and offline), and health (overall health state, lifestyle, and cancer), with dimensions of behavior and attitude. The questions are organized with more of the behavior dimension (average percentage of $53.8 \%$ ) than attitude (average percentage of $30.4 \%$ ) (Table 2). The analysis of the survey questionnaire contents conceptualized the HISB phenomenon, showing 3 
domains, namely, information, channel, and health, with 2 dimensions, namely, behavior (objective outcome) and attitude (subjective tendency), emerging from the information-channel-health structure (Figure 5). In recent years, research has been conducted in parallel with existing reviews and meta-analysis to bring a theoretical framework to make some corrections [20] or to compare only specific variables to analyze the relationships [85] deductively. This study is meaningful as it derives a theoretical framework inductively after analyzing the contents by reviewing all the items of survey questionnaires. The findings of this study revealed that nationally representative surveys of HISB did not report theoretical frameworks when constructing the questionnaires. Therefore, it is believed that the outcomes of this study can be helpful in developing HISB-related tools or in establishing a theoretical framework prior to a large-scale investigation. This study included comprehensive (online and offline) HISBs. Recently, the terms eHealth and mobile health have become popular as many people use the internet and mobile access to manage their health. Therefore, preliminary review studies have focused on web-based HISBs or eHealth [17]. This research trend has a limitation in that it fails to address offline sources or face-to-face HISBs that still account for a large portion of HISBs.

This study found that all the survey instruments were from high-income countries, that is, United States, European Union, France, Germany, Israel, Poland, South Korea, and Taiwan, of the Organization for Economic Co-operation and Development [86]. The results can be interpreted as showing that there is information inequality, which may lead to a worsening of health inequality between high-income and low- and-middle-income countries. While low- and-middle-income countries still prioritize the establishment of universal health coverage focusing on the provider, high-income countries acknowledge the health information for individuals, empowering the health care consumer. The gap might be overcome through assessment of the trend of HISB in low- and-middle-income countries to contribute to the effective and efficient health care service to be provided. The details were analyzed by reviewing individual questions for the 13 survey tools, which were deeply rooted in the countries' differences. There are deviations in the questions according to the culture or medical system. For example, the question options vary depending on whether the countries are exposed to terrorism or have specific diseases or causes of cancer such as ultraviolet radiation exposure followed by a high incidence of skin cancer. In addition, questions about the type of health insurance and Medicare system also varied-for example, whether to visit in-store retail clinics, where to receive prescriptions, differences in the quality of and satisfaction with medical services, and accessibility to medical services.

The degree of information technology development in the country also has a great influence on the questions. The question asking whether the respondent has computers or mobile/smart devices depends on the development of information technology and the retention rate of mobile phones in each country. As an extension of this question, questions were subdivided into digital literacy, the type of fitness app, and whether web-based chat groups were used for health-related topics. With HINTS as a standard, related studies from Germany, South Korea, and China were also developed. HINTS Germany was established by HINTS (United States) and supported by the National Cancer Institute. In the case of South Korea, an individual researcher developed the survey questionnaires based on the content of HINTS and was funded by a national institute. HINTS China was excluded in this study because researchers did not conduct a nationally representative sample survey of the country. These studies would enable cross-national trend analysis and agenda for HISB.

\section{Limitations and Recommendations for Future Research}

For this study, we used databases in English and Korean, but there are some survey instruments that are neither English nor Korean. To overcome this limitation, we did not limit the languages in the search process. Moreover, it is obvious that English is the universal language of publication in the research field in the era of globalization. Therefore, we also used surveys in other languages, including 1 from France (French), Germany (German), and South Korea (Korean) in this paper. Some full versions of HISB survey instruments were not available for the review process. To attain the instrument, the researchers emailed corresponding authors for the HISB survey tools; however, these were found to be not related to HISB, or the author refused to provide a full version, or we received no response. In addition, the duration of the literature search was restricted to the period between 2008 and 2020. However, we mitigated this limitation because this study's findings cover the fundamental essence of HISB phenomena by analyzing existing tools over a more extensive period. The theoretical framework derived from this study could be used as a guide for nationally representative HISB surveys. From the findings of this study, we see that there was a lack of theoretical basis for the survey instrument. The framework including both the behavior/attitude and online/offline dimensions would provide integrative scope for national HISB phenomena. Moreover, this framework could be compared to other HISB-related theories, thereby enabling more comprehensive insight into the HISB phenomenon. As the study scope focused on HISB instruments that seek nationally representative samples, future studies could also analyze different populations, including certain regions, ages, genders, and occupations with HISB instruments. It would be worthy to compare the differences among the populations.

\section{Conclusion}

This study analyzed and synthesized current HISB survey questionnaires for nationally representative surveys. The findings of the methodology and content analysis provide a map and prototype for developing HISB-related instruments. A theoretical framework including both behavior/attitude and online/offline dimensions may provide integrative insight into real-world HISB phenomena. In sum, the findings of this study may contribute to better understanding of comprehensive HISB trends in nationally representative surveys. 


\section{Acknowledgments}

This research was supported by the National Research Foundation of Korea (NRF-2019R1F1A1058969, 2017R1D1A1B03035510) and Nambu University, 2020.We thank Jamie Conklin (Health Sciences Librarian at University of North Carolina at Chapel Hill) who helped in the search process.

\section{Conflicts of Interest}

None declared.

\section{Multimedia Appendix 1}

Search strategies used for the study.

[PDF File (Adobe PDF File), 208 KB-Multimedia Appendix 1]

\section{Multimedia Appendix 2}

List of studies related to each health information-seeking behavior survey instrument tool.

[PDF File (Adobe PDF File), 172 KB-Multimedia Appendix 2]

\section{Multimedia Appendix 3}

Characteristics of the health information-seeking behavior survey instruments.

[PDF File (Adobe PDF File), 191 KB-Multimedia Appendix 3]

\section{Multimedia Appendix 4}

Theme occurrence table.

[PDF File (Adobe PDF File), 241 KB-Multimedia Appendix 4]

\section{References}

1. COVID-19 as a public health emergency of international concern (PHEIC) under the IHR. World Health Organization URL: https://extranet.who.int/sph/covid-19-public-health-emergency-international-concern-pheic-under-ihr [accessed 2021-01-04]

2. Hernández-García I, Giménez-Júlvez T. Assessment of Health Information About COVID-19 Prevention on the Internet: Infodemiological Study. JMIR Public Health Surveill 2020 Apr 01;6(2):e18717. [doi: 10.2196/18717] [Medline: 32217507]

3. Moreno A, Fuentes-Lara C, Navarro C. Covid-19 communication management in Spain: Exploring the effect of information-seeking behavior and message reception in public's evaluation. EPI 2020 May 29;29(4):e290402. [doi: 10.3145/epi.2020.jul.02]

4. Call for action: Managing the infodemic. World Health Organization. URL: https://www.who.int/news/item/ 11-12-2020-call-for-action-managing-the-infodemic [accessed 2021-01-04]

5. Associated Press. Coronavirus: In Iran, the false belief that toxic methanol fights Covid-19 kills hundreds. South China Morning Post. 2020 Mar 27. URL: https://www.scmp.com/news/world/middle-east/article/3077284/ coronavirus-iran-false-belief-toxic-methanol-fights-covid-19 [accessed 2021-01-01]

6. Kim HK, Ahn J, Atkinson L, Kahlor LA. Effects of COVID-19 Misinformation on Information Seeking, Avoidance, and Processing: A Multicountry Comparative Study. Science Communication 2020 Sep 13;42(5):586-615. [doi: $10.1177 / 1075547020959670]$

7. Park C. Coronavirus: saltwater spray infects 46 church-goers in South Korea. South China Morning Post. URL: https:/ /www.scmp.com/week-asia/health-environment/article/3075421/coronavirus-salt-water-spray-infects-46-church-goers [accessed 2021-01-04]

8. Zarocostas J. How to fight an infodemic. The Lancet 2020 Feb;395(10225):676. [doi: 10.1016/s0140-6736(20)30461-x]

9. Bento AI, Nguyen T, Wing C, Lozano-Rojas F, Ahn Y, Simon K. Evidence from internet search data shows information-seeking responses to news of local COVID-19 cases. Proc Natl Acad Sci U S A 2020 May 26;117(21):11220-11222 [FREE Full text] [doi: 10.1073/pnas.2005335117] [Medline: 32366658]

10. Lambert SD, Loiselle CG. Health information seeking behavior. Qual Health Res 2007 Oct;17(8):1006-1019. [doi: 10.1177/1049732307305199] [Medline: 17928475]

11. Zimmerman MS, Shaw G. Health information seeking behaviour: a concept analysis. Health Info Libr J 2020 Sep;37(3):173-191. [doi: 10.1111/hir.12287] [Medline: 32052549]

12. Shaffer KM, Nightingale CL. Comparison of Healthcare Utilization Between Informal Caregivers and Non-Caregivers: An Analysis of the Health Information National Trends Survey. J Aging Health 2020;32(5-6):453-461 [FREE Full text] [doi: 10.1177/0898264319830262] [Medline: $\underline{30793639}$ ] 
13. Rising CJ, Jensen RE, Moser RP, Oh A. Characterizing the US Population by Patterns of Mobile Health Use for Health and Behavioral Tracking: Analysis of the National Cancer Institute's Health Information National Trends Survey Data. J Med Internet Res 2020 May 14;22(5):e16299 [FREE Full text] [doi: 10.2196/16299] [Medline: $\underline{32406865}$ ]

14. O'Donnell JM, Jelinek GA, Gray KM, De Livera A, Brown CR, Neate SL, et al. Therapeutic utilization of meditation resources by people with multiple sclerosis: insights from an online patient discussion forum. Inform Health Soc Care 2020 Oct 01;45(4):374-384. [doi: 10.1080/17538157.2020.1755975] [Medline: $\underline{32508186]}$

15. Calixte R, Rivera A, Oridota O, Beauchamp W, Camacho-Rivera M. Social and Demographic Patterns of Health-Related Internet Use Among Adults in the United States: A Secondary Data Analysis of the Health Information National Trends Survey. Int J Environ Res Public Health 2020 Sep 19;17(18):6856 [FREE Full text] [doi: 10.3390/ijerph17186856] [Medline: 32961766]

16. Mano R. Use of Mobile Health Applications and the Self-Management of Cancer: A Gendered Approach. OJPM 2019;09(10):126-139. [doi: 10.4236/ojpm.2019.910012]

17. Hong Y, Cho J. Assessment of eHealth behaviors in national surveys: a systematic review of instruments. J Am Med Inform Assoc 2018 Dec 01;25(12):1675-1684 [FREE Full text] [doi: 10.1093/jamia/ocy128] [Medline: 30357344]

18. Bigsby E, Hovick SR. Understanding Associations between Information Seeking and Scanning and Health Risk Behaviors: An Early Test of the Structural Influence Model. Health Commun 2018 Mar;33(3):315-325. [doi:

10.1080/10410236.2016.1266575] [Medline: 28059570]

19. Phillips A. Proper Applications for Surveys as a Study Methodology. West J Emerg Med 2017 Jan;18(1):8-11 [FREE Full text] [doi: 10.5811/westjem.2016.11.32000] [Medline: 28116000]

20. Wang X, Shi J, Kong H. Online Health Information Seeking: A Review and Meta-Analysis. Health Commun 2020 Apr 14:1-13. [doi: 10.1080/10410236.2020.1748829] [Medline: 32290679]

21. Cooke A, Smith D, Booth A. Beyond PICO: the SPIDER tool for qualitative evidence synthesis. Qual Health Res 2012 Oct;22(10):1435-1443. [doi: 10.1177/1049732312452938] [Medline: 22829486]

22. Methley AM, Campbell S, Chew-Graham C, McNally R, Cheraghi-Sohi S. PICO, PICOS and SPIDER: a comparison study of specificity and sensitivity in three search tools for qualitative systematic reviews. BMC Health Serv Res 2014 Nov 21;14:579 [FREE Full text] [doi: 10.1186/s12913-014-0579-0] [Medline: 25413154]

23. Moher D, Liberati A, Tetzlaff J, Altman DG, PRISMA Group. Preferred reporting items for systematic reviews and meta-analyses: the PRISMA statement. PLoS Med 2009 Jul 21;6(7):e1000097 [FREE Full text] [doi:

10.1371/journal.pmed.1000097] [Medline: 19621072]

24. Global Health Data Exchange. URL: https://ghdx.healthdata.org/ [accessed 2021-02-17]

25. Health information national trends survey (HINTS) 5, cycle 3. National Cancer Institute. URL: https://hints.cancer.gov/ data/survey-instruments.aspx [accessed 2021-02-17]

26. Health tracking survey. Pew Research Center. 2012. URL: https://www.pewresearch.org/internet/dataset/ september-2012-health-tracking-prelim/ [accessed 2021-02-17]

27. Annenberg National Health Communication Survey (ANHCS). URL: https://anhcs.asc.upenn.edu/ [accessed 2021-02-17]

28. National health interview survey (NHIS). Centers for Disease Control and Prevention. URL: https://www.cdc.gov/nchs/ nhis/data-questionnaires-documentation.htm [accessed 2021-02-17]

29. Health tracking household survey (HTHS). Health and Medical Care Archive. 2010. URL: https://www.icpsr.umich.edu/ web/HMCA/studies/34141 [accessed 2021-02-17]

30. Flash eurobarometer 404 (European citizen's digital health literacy). EU Open Data Portal. 2014. URL: https://data.europa.eu/ data/datasets/s2020 404?locale=en [accessed 2021-02-17]

31. French health barometer (Baromètre santé). Sante Publique France. 2017. URL: https://www.santepubliquefrance.fr/ etudes-et-enquetes/barometres-de-sante-publique-france/barometre-sante-2017 [accessed 2021-02-17]

32. Gesundheitsmonitor (Bertelsmann Healthcare Monitor). 2015. URL: https://www.bertelsmann-stiftung.de/fileadmin/files/ BSt/Publikationen/imported/abstract/1 680 Abstract.pdf [accessed 2021-02-17]

33. Hayat TZ, Brainin E, Neter E. With Some Help From My Network: Supplementing eHealth Literacy With Social Ties. J Med Internet Res 2017 Mar 30;19(3):e98 [FREE Full text] [doi: 10.2196/jmir.6472] [Medline: 28360024]

34. Bujnowska-Fedak MM. Trends in the use of the Internet for health purposes in Poland. BMC Public Health 2015 Feb 27;15:194 [FREE Full text] [doi: 10.1186/s12889-015-1473-3] [Medline: 25886280]

35. Stiftung Gesundheitswissen. HINTS Germany. 2019. URL: https://www.stiftung-gesundheitswissen.de/projekt-hints-germany [accessed 2021-02-17]

36. Hanna C. Classification of health information-seeking behavior among Korean adults. 2020 Presented at: The 23rd East Asian Forum of Nursing Scholars (EAFONS); Jan 10-11, 2020; Chiang Mai, Thailand.

37. Taiwan communication survey (TCS). Ministry of Science and Technology. 2016. URL: https://www.crctaiwan.nctu.edu.tw/ annualsurvey_e.asp [accessed 2021-02-17]

38. Arora NK, Hesse BW, Rimer BK, Viswanath K, Clayman ML, Croyle RT. Frustrated and confused: the American public rates its cancer-related information-seeking experiences. J Gen Intern Med 2008 Mar;23(3):223-228 [FREE Full text] [doi: 10.1007/s11606-007-0406-y] [Medline: 17922166] 
39. Beckjord EB, Finney Rutten LJ, Arora NK, Moser RP, Hesse BW. Information processing and negative affect: evidence from the 2003 Health Information National Trends Survey. Health Psychol 2008 Mar;27(2):249-257. [doi: 10.1037/0278-6133.27.2.249] [Medline: 18377144]

40. Shim M. Connecting internet use with gaps in cancer knowledge. Health Commun 2008 Sep;23(5):448-461. [doi: 10.1080/10410230802342143] [Medline: 18850392 ]

41. Van Stee SK, Yang Q. Online Cancer Information Seeking: Applying and Extending the Comprehensive Model of Information Seeking. Health Commun 2018 Dec;33(12):1583-1592. [doi: 10.1080/10410236.2017.1384350] [Medline: 29083231]

42. Chisolm DJ. Does online health information seeking act like a health behavior?: a test of the behavioral model. Telemed J E Health 2010 Mar;16(2):154-160. [doi: 10.1089/tmj.2009.0102] [Medline: 20156127]

43. Chisolm DJ, Sarkar M. E-health use in african american internet users: can new tools address old disparities? Telemed J E Health 2015 Mar;21(3):163-169. [doi: 10.1089/tmj.2014.0107] [Medline: 25536065]

44. Ardito S. Seeking consumer health information on the internet. Information Today Inc. 2013. URL: https://www. infotoday.com/OnlineSearcher/Articles/Medical-Digital/Seeking-Consumer-Health-Information-on-the-Internet-90558. shtml [accessed 2021-06-23]

45. Kuehn BM. More than one-third of US individuals use the Internet to self-diagnose. JAMA 2013 Feb 27;309(8):756-757. [doi: 10.1001/jama.2013.629] [Medline: 23443421]

46. Oh YS, Cho Y. Examining the relationships between resources and online health information seeking among patients with chronic diseases and healthy people. Soc Work Health Care 2015;54(2):83-100. [doi: 10.1080/00981389.2014.987940] [Medline: 25674723]

47. Ruggiero KJ, Gros DF, McCauley J, de Arellano MA, Danielson CK. Rural adults' use of health-related information online: data from a 2006 National Online Health Survey. Telemed J E Health 2011 Jun;17(5):329-334 [FREE Full text] [doi: 10.1089/tmj.2010.0195] [Medline: 21524201]

48. Saulsberry L, Price M, Hsu J. Medicare Medicaid Res Rev 2014;4(4):mmrr2014-004-04-b01 [FREE Full text] [doi: 10.5600/mmrr.004.04.b01] [Medline: 25383242]

49. Stern MJ, Cotten SR, Drentea P. The Separate Spheres of Online Health. Journal of Family Issues 2011 Oct 21;33(10):1324-1350. [doi: 10.1177/0192513X11425459]

50. Sun Y, Liu M, Krakow M. Health e-mavens: identifying active online health information users. Health Expect 2016 Oct;19(5):1071-1083 [FREE Full text] [doi: 10.1111/hex.12398] [Medline: 26296041]

51. Hovick SR, Bigsby E. Heart Disease and Colon Cancer Prevention Beliefs and Their Association With Information Seeking and Scanning. J Health Commun 2016;21(1):76-84. [doi: 10.1080/10810730.2015.1049307] [Medline: 26444664]

52. Ishikawa Y, Kondo N, Kawachi I, Viswanath K. Are socioeconomic disparities in health behavior mediated by differential media use? Test of the communication inequality theory. Patient Educ Couns 2016 Nov;99(11):1803-1807. [doi: 10.1016/j.pec.2016.05.018] [Medline: 27349600]

53. Kim S. An exploratory study of inactive health information seekers. Int J Med Inform 2015 Feb;84(2):119-133 [FREE Full text] [doi: 10.1016/j.ijmedinf.2014.10.003] [Medline: 25453277]

54. Lee CJ. Does the internet displace health professionals? J Health Commun 2008;13(5):450-464. [doi: 10.1080/10810730802198839] [Medline: 18661387]

55. Yang Q, Chen Y, Wendorf Muhamad J. Social Support, Trust in Health Information, and Health Information-Seeking Behaviors (HISBs): A Study Using the 2012 Annenberg National Health Communication Survey (ANHCS). Health Commun 2017 Sep;32(9):1142-1150. [doi: 10.1080/10410236.2016.1214220] [Medline: 27589249]

56. Li W, Watts J, Tan N. From Screen to Screening: Entertainment and News Television Media Effects on Cancer Screening Behaviors. J Health Commun 2019;24(4):385-394. [doi: 10.1080/10810730.2019.1607954] [Medline: 31033423 ]

57. Amante DJ, Hogan TP, Pagoto SL, English TM, Lapane KL. Access to care and use of the Internet to search for health information: results from the US National Health Interview Survey. J Med Internet Res 2015 Apr 29;17(4):e106 [FREE Full text] [doi: $\underline{10.2196 / j m i r .4126]}$ [Medline: 25925943]

58. Dahlhamer JM, Galinsky AM, Joestl SS, Ward BW. Sexual Orientation and Health Information Technology Use: A Nationally Representative Study of U.S. Adults. LGBT Health 2017 Apr;4(2):121-129 [FREE Full text] [doi: 10.1089/lgbt.2016.0199] [Medline: 28287875]

59. US Centers For Disease Control And Prevention Epilepsy Program. Internet use and looking up information online in adults with epilepsy varies by epilepsy status--2013 National Health Interview Survey. Epilepsy Behav 2016 Jan;54:47-49. [doi: 10.1016/j.yebeh.2015.10.019] [Medline: 26655448]

60. Zhang Y, Lauche R, Sibbritt D, Olaniran B, Cook R, Adams J. Comparison of Health Information Technology Use Between American Adults With and Without Chronic Health Conditions: Findings From The National Health Interview Survey 2012. J Med Internet Res 2017 Oct 05;19(10):e335 [FREE Full text] [doi: 10.2196/jmir.6989] [Medline: 28982644]

61. Gonzalez M, Sanders-Jackson A, Wright T. Web-Based Health Information Technology: Access Among Latinos Varies by Subgroup Affiliation. J Med Internet Res 2019 Apr 16;21(4):e10389 [FREE Full text] [doi: 10.2196/10389] [Medline: 30990462] 
62. Kindratt T, Callender L, Cobbaert M, Wondrack J, Bandiera F, Salvo D. Health information technology use and influenza vaccine uptake among US adults. Int J Med Inform 2019 Sep;129:37-42. [doi: 10.1016/j.ijmedinf.2019.05.025] [Medline: $\underline{31445279]}$

63. Heckman CJ, Handorf E, Auerbach MV. Prevalence and Correlates of Skin Cancer Screening Among Indoor Tanners and Nontanners. JAMA Dermatol 2018 May 01;154(5):554-560 [FREE Full text] [doi: 10.1001/jamadermatol.2018.0163] [Medline: 29617518]

64. Hong Y, Hincapie-Castillo JM, Xie Z, Segal R, Mainous AG. Socioeconomic and Demographic Characteristics of US Adults Who Purchase Prescription Drugs From Other Countries. JAMA Netw Open 2020 Jun 01;3(6):e208968 [FREE Full text] [doi: 10.1001/jamanetworkopen.2020.8968] [Medline: 32579194]

65. Lee JH, Giovenco D, Operario D. Patterns of Health Information Technology Use according to Sexual Orientation among US Adults Aged 50 and Older: Findings from a National Representative Sample-National Health Interview Survey 2013-2014. J Health Commun 2017 Aug;22(8):666-671 [FREE Full text] [doi: 10.1080/10810730.2017.1341566] [Medline: 28749748]

66. Mahajan S, Lu Y, Spatz ES, Nasir K, Krumholz HM. Trends and Predictors of Use of Digital Health Technology in the United States. Am J Med 2021 Jan;134(1):129-134. [doi: 10.1016/j.amjmed.2020.06.033] [Medline: 32717188]

67. Yin R, Neyens DM. Online Health Resource Use by Individuals With Inflammatory Bowel Disease: Analysis Using the National Health Interview Survey. J Med Internet Res 2020 Sep 24;22(9):e15352 [FREE Full text] [doi: 10.2196/15352] [Medline: 32969831]

68. Rooks RN, Wiltshire JC, Elder K, BeLue R, Gary LC. Health information seeking and use outside of the medical encounter: is it associated with race and ethnicity? Soc Sci Med 2012 Jan;74(2):176-184. [doi: 10.1016/j.socscimed.2011.09.040] [Medline: 22154611]

69. Wiltshire JC, Roberts V, Brown R, Sarto GE. The effects of socioeconomic status on participation in care among middle-aged and older adults. J Aging Health 2009 Mar;21(2):314-335. [doi: 10.1177/0898264308329000] [Medline: 19091692]

70. Rooks RN, Kapral CG, Mathis AL. Chronic Conditions May Be More Important Than Race or Ethnicity in Relation to Health Information Seeking and Use. J Aging Health 2019 Apr;31(4):611-630. [doi: 10.1177/0898264317744643] [Medline: 29254425]

71. Dean CA, Geneus CJ, Rice S, Johns M, Quasie-Woode D, Broom K, et al. Assessing the significance of health information seeking in chronic condition management. Patient Educ Couns 2017 Aug;100(8):1519-1526. [doi: 10.1016/j.pec.2017.03.012] [Medline: 28320559]

72. Reifegerste D, Bachl M, Baumann E. Surrogate health information seeking in Europe: Influence of source type and social network variables. Int J Med Inform 2017 Jul;103:7-14. [doi: 10.1016/j.ijmedinf.2017.04.006] [Medline: 28551004]

73. Beck F, Richard J, Nguyen-Thanh V, Montagni I, Parizot I, Renahy E. Use of the internet as a health information resource among French young adults: results from a nationally representative survey. J Med Internet Res 2014 May 13;16(5):e128 [FREE Full text] [doi: 10.2196/jmir.2934] [Medline: 24824164]

74. Baumann E, Czerwinski F, Reifegerste D. Gender-Specific Determinants and Patterns of Online Health Information Seeking: Results From a Representative German Health Survey. J Med Internet Res 2017 Apr 04;19(4):e92 [FREE Full text] [doi: 10.2196/jmir.6668] [Medline: 28377367]

75. Baumann E, Czerwinski F, Rosset M, Seelig M, Suhr R. [How do people in Germany seek health information? Insights from the first wave of HINTS Germany]. Bundesgesundheitsblatt Gesundheitsforschung Gesundheitsschutz 2020 Sep;63(9):1151-1160. [doi: 10.1007/s00103-020-03192-x] [Medline: 32666180]

76. Bujnowska-Fedak MM. Trends in the use of the Internet for health purposes in Poland. BMC Public Health 2015 Feb 27;15:194 [FREE Full text] [doi: 10.1186/s12889-015-1473-3] [Medline: 25886280]

77. Chang C. Self-Control-Centered Empowerment Model: Health Consciousness and Health Knowledge as Drivers of Empowerment-Seeking through Health Communication. Health Commun 2020 Nov;35(12):1497-1508. [doi: 10.1080/10410236.2019.1652385] [Medline: 31480856]

78. eHealth Consumer Trends Survey. 2007. URL: https://www.jmir.org/api/ download?filename=a211f33fdca62ea09403094624688af0.pdf\&alt_name=1023-5010-1-SP.pdf [accessed 2021-02-17]

79. Tove S. WHO/European eHealth consumer trends survey (final project report). Norwegian Center for eHealth Research. URL: https://ehealthresearch.no/en/reports/archive/who-european-ehealth-consumer-trends-survey [accessed 2021-02-17]

80. Rosenberg M, Hovland C. Cognitive, affective, and behavioral components of attitudes. In: McGuire W, Abelson R, Brehm J, editors. Attitude organization and change: An Analysis of Consistency Among Attitude Components. New Haven, CT: Yale University Press; 1960:1-14.

81. American Psychological Association (APA) Dictionary of Psychology. URL: https://dictionary.apa.org/ [accessed 2021-01-04]

82. Branscum P, Hayes L, Wallace L. Direct observation of searching for online health information: A systematic review of current evidence. American Journal of Health Studies. 2016. URL: https://www.amjhealthstudies.com/index.php/ajhs/ article/view/154 [accessed 2021-06-22]

83. Pian W, Song S, Zhang Y. Consumer health information needs: A systematic review of measures. Information Processing \& Management 2020 Mar;57(2):102077. [doi: 10.1016/j.ipm.2019.102077]

84. Kubb C, Foran HM. Online Health Information Seeking by Parents for Their Children: Systematic Review and Agenda for Further Research. J Med Internet Res 2020 Aug 25;22(8):e19985 [FREE Full text] [doi: 10.2196/19985] [Medline: 32840484] 
85. McMullan RD, Berle D, Arnáez S, Starcevic V. The relationships between health anxiety, online health information seeking, and cyberchondria: Systematic review and meta-analysis. J Affect Disord 2019 Feb 15;245:270-278. [doi:

10.1016/j.jad.2018.11.037] [Medline: $\underline{30419526]}$

86. Doing business 2020: OECD high-income economies remain global benchmarks on most doing business indicators. The World Bank. URL: https://www.worldbank.org/en/news/press-release/2019/10/24/

doing-business-2020-oecd-high-income-economies-remain-global-benchmarks-on-most-doing-business-indicators [accessed 2021-06-14]

\author{
Abbreviations \\ ANHCS: Annenberg National Health Communication Survey \\ CHISB: cancer and health-related information-seeking behavior \\ HINTS: Health Information National Trends Survey \\ HISB: health information-seeking behavior \\ HTHS: Health Tracking Household Survey \\ NHIS: National Health Interview Survey \\ RISS: Research Information Sharing Service
}

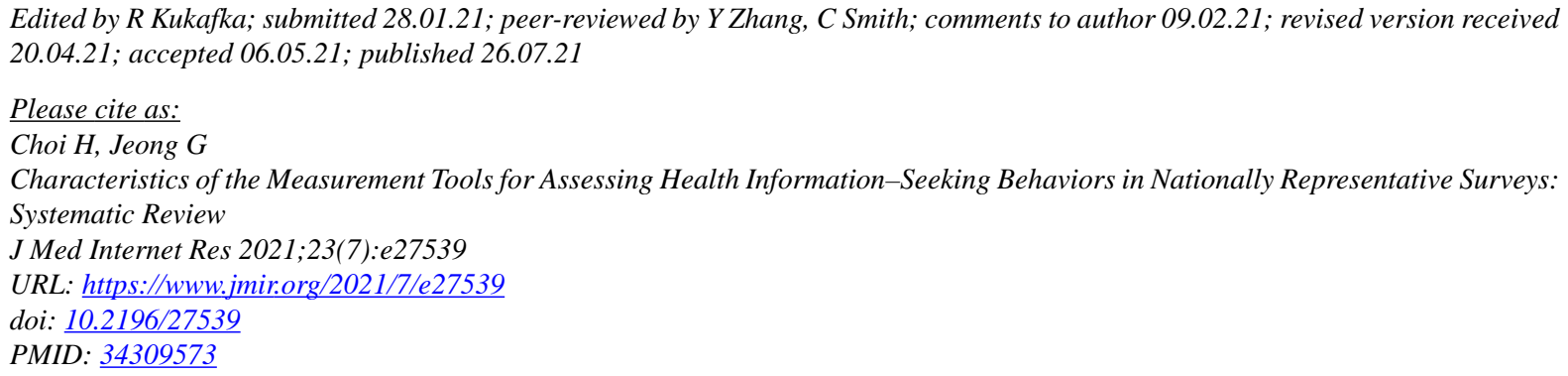

CHanna Choi, Gyeonghui Jeong. Originally published in the Journal of Medical Internet Research (https://www.jmir.org), 26.07.2021. This is an open-access article distributed under the terms of the Creative Commons Attribution License (https://creativecommons.org/licenses/by/4.0/), which permits unrestricted use, distribution, and reproduction in any medium, provided the original work, first published in the Journal of Medical Internet Research, is properly cited. The complete bibliographic information, a link to the original publication on https://www.jmir.org/, as well as this copyright and license information must be included. 